\title{
Flipping the College English Classroom
}

\author{
YUAN Jing-jing \\ Linyi University, Linyi, China
}

\begin{abstract}
The flipped classroom is an emerging teaching mode which is originated from the United States and is now prevalent in many countries. It is helpful to build a more harmonious relationship between the teachers and the students, to enhance the students' self-study ability, to create a favorable learning environment, to realize the individualized teaching in class, and to improve the students' English ability. The study focuses on the college English classroom in China. The author tries to prove that the flipped classroom is a helpful way to improve the teaching and learning effect of college English classroom. A teaching procedure for the flipped college English classroom is designed in the hope of changing the current college English teaching condition.
\end{abstract}

Keywords: the flipped classroom, college English, activities design

\section{Introduction}

In the People's Republic of China, College English (CE) is an English-language course offered to non-English majors in 1,983 universities. As of 2004, there were about 50,000 Chinese English teachers teaching CE to an estimated 19,000,000 students (WU, 2004). CE instruction in Chinese universities has sometimes been labelled as "deaf and dumb English" (DU, 2012, p. 1). Through many times of reforms, the effect of CE is still not satisfying. The current situation is that the credit and class hours of CE are reduced. So the new task of College English teaching is to transmit useful knowledge, maximize the effect of classroom teaching, and truly promote the college students' English ability.

The flipped classroom originated from the United States. Its student-centred principle and new teaching forms spread quickly in countries all over the world. Now the flipped classroom has become a world-renowned effective teaching mode. Now, more and more universities in China start to adopt this new teaching method. However, it is not rational to just "get and use" it. We should take our own teaching condition into consideration. This paper tries to introduce the relevant concepts and the advantages of the flipped classroom and to design the whole process of the flipped college English classroom in China.

\section{The General Concept of the Flipped Classroom}

In 2000, in the paper Inverting the Classroom: A Gateway to Creating an Inclusive Learning Environment, Maureen Lage, Glenn Platt, and Michael Treglia introduced how they used inverted classroom model in their economic classes and the achievements they have got. However, they did not propose the definition of the "flipped classroom".

In 2007, Wookland Park High School's chemistry teachers Jonathan Bergman and Aaron Sams proposed the term "the flipped classroom" by recording their lectures and posted them online in order to accommodate

YUAN Jing-jing, teaching assistant, Ph.D. candidate, Foreign Language School, Linyi University. 
students who missed their classes. Afterwards, they asked all their students to self-study the videos before the class and in the class they only discussed the videos and help the students to solve the problems they have encountered (Y. G. ZHANG \& Y. J. ZHANG, 2012). From then on, the flipped classroom model became prevalent in the primary and middle schools.

In 2011, Salman Kahhan set up Khan Academy. In the website of this academy there were more than 3,500 teaching videos. In the meantime, the website also offered some learning tools for online exercising, self-assessing, and the following-up tracing (H. J. ZHU \& B. ZHU, 2013). In 2011, Salman Khan mentioned the concept of "using videos to rebuild education". The flipped classroom of Khan Academy was taken as a ray of hope for the future education.

Then, what is the flipped classroom model?

The flipped classroom describes a reversal of traditional teaching where students gain first exposure to new material outside of class, usually via reading or lecture videos, and then class time is used to do the harder work of assimilating that knowledge through strategies such as problem-solving, discussion, or debates (Brame, 2013).

The core of the flipped classroom is to turn the classroom into a place where the teachers and students can solve problems together and the students study cooperatively to fully utilize the class hours.

\section{The Differences Between Traditional Classrooms and the Flipped Classrooms}

Teaching involves teaching processes in which the teachers impart knowledge and learning processes in which the students absorb knowledge. For traditional teaching, the students preview what they will learn before the class. Then, the teachers teach new knowledge to them and finally the students review what they have learned through doing some exercises. As for the assessment system, although many schools and universities adopt the formative evaluation and the summative evaluation, the final outcome depends mostly on the latter scores. In this process, the teachers are knowledge transmitters and the students are passive receivers of knowledge. Students are not the masters of their own learning in this process.

In the flipped classrooms, the teachers are instructors and promoters. The students learn through active study and discussion. Before the class, the students watch teaching videos and finish the relevant tasks. In the classroom, the teachers and students work together to solve the problems posed by the video. So compared with the traditional teaching, the teachers and students in the flipped classroom have more communications and the students are more dependent. After class, the teachers would reflect on all the activities to make them more reasonable and scientific. The students summarize what they have learned to improve themselves. For the final assessment, the teachers use a dynamic evaluation based on the whole process of learning.

Table 1

The Differences Between Traditional Classrooms and the Flipped Classrooms (WANG \& ZHANG, 2013)

\begin{tabular}{|c|c|c|c|c|}
\hline \multicolumn{3}{|c|}{ Teaching procedure } & \multirow{2}{*}{$\begin{array}{l}\text { Traditional classroom } \\
\text { Get a rough grasp of the } \\
\text { learning material }\end{array}$} & \multirow{2}{*}{$\begin{array}{l}\text { Flipped classroom } \\
\text { Grasp the basic content and finish the requirements }\end{array}$} \\
\hline \multirow{6}{*}{ Before class } & \multirow{3}{*}{ Preview } & Function & & \\
\hline & & Form & Read by the students & Read the text books and other materials and watch the videos \\
\hline & & Feedback & No & To get to know the effect of the students' study through certain tests \\
\hline & \multirow{3}{*}{ Exercise } & Function & No special requirements & $\begin{array}{l}\text { Through exercises and tests to get to know the preview condition } \\
\text { of the students in order to adjust the classroom activity before the } \\
\text { class }\end{array}$ \\
\hline & & Form & The students do exercises & Online exercises or tests \\
\hline & & Feedback & No & $\begin{array}{l}\text { Immediate feedback } \\
\text { Teach and discuss }\end{array}$ \\
\hline
\end{tabular}


(Table 1 continued)

\begin{tabular}{|c|c|c|c|c|}
\hline \multicolumn{3}{|c|}{ Teaching procedure } & \multirow{2}{*}{$\begin{array}{l}\text { Traditional classroom } \\
\text { Help the students to } \\
\text { understand the content }\end{array}$} & Flipped classroom \\
\hline \multirow{3}{*}{ In the class } & \multirow{3}{*}{ Explanation } & Purpose & & $\begin{array}{l}\text { Help the students solve their puzzles, lead the students to } \\
\text { summarize what they have learned }\end{array}$ \\
\hline & & Content & All the contents & $\begin{array}{l}\text { The problems, puzzles and understandings of the students after } \\
\text { watching the videos }\end{array}$ \\
\hline & & Form & Explanation & Answer questions, discussion, teaching and explanation \\
\hline \multirow{3}{*}{ After class } & \multirow{3}{*}{ Assignment } & Purpose & $\begin{array}{l}\text { Strengthen the } \\
\text { comprehension }\end{array}$ & Lead the students to reflect and summarize what they have learned \\
\hline & & Form & $\begin{array}{l}\text { The teachers assign } \\
\text { tasks to the students }\end{array}$ & Exercises and discussion \\
\hline & & Guidance & No & Teachers offer online instruction through the internet \\
\hline Platform & & & No & $\begin{array}{l}\text { Use the network teaching platform to issue the learning } \\
\text { instructions, resources, videos, online tests and give the feedbacks }\end{array}$ \\
\hline
\end{tabular}

\section{The Design of the Flipped College English Classroom}

In China, CE is usually a comprehensive course which means that there is no separated listening, speaking, reading, and writing classes. What is more, the average class hours for CE every week are only four hours. This kind of arrangement actually puts forward higher demand for college English teachers. So how to design the whole procedure of English class to really improve college students' English level and at the same time to make the students to be interested and to be active to participate in the class is very important. The flipped English classroom is a good way to solve the above problems. Now we are going to design a whole procedure for the flipped college English class.

\section{Pre-class Activities}

The major difference between the pre-class activities in the flipped classes and that in the traditional class is that the former is a designed and task-based one while the latter is not. The students need to perform some tasks, find out the problems and bring them to the class to discuss them with the teachers and other classmates. For designing the activities, the teachers need to find out the key points and difficult points in every class and to design different kinds of activities to arouse the students' interest. The students should also attach great importance to the activities and to be prepared before the class. Without the two parts completed, the effect of the following parts would be greatly reduced.

Teachers make the teaching videos. First of all, the teachers should have an overall grasp of the whole textbook including the topics, the key points, and difficult points. When designing pre-class activities, each class should have its teaching objectives and proper forms are used to show the objectives. Secondly, when making the teaching videos, the teachers should put more emphasis on improving the students' listening and speaking ability. Finally, in order to guarantee the teaching effect, the teachers should make concrete objects for each part, make proper exercises or tests, and urge the students to finish the tasks on time.

Students watch the teaching videos. First of all, while watching the videos, the students can take charge of the watching speed and time. The advantage is that the students whose English is not so good can spend more time on watching them thus can finish all the tasks. That would solve the problem of one class containing learners of different proficiency levels. Secondly, students should try every way to solve the problems that are within their ability and leave the ones that are beyond their ability to be solved in the class.

Teachers and students discuss through certain communication platform. New technologies provide more media for the teacher and students to communicate and to solve some problems before class such as QQ 
or V-chat. By this way, the students may have more chances to communicate with the teachers and other classmates and can get over of the feeling of tension while they are communicating face to face with the teachers.

\section{Classroom Activity}

HUANG Yang (2014) proposed four steps for the flipped classroom. First, check the students' preview. Second, give the takes in the class step by step. Third, hold the cooperation part to help the students to solve their difficulties. Fourth, let the students show what they have learned by the form of group report.

Using his procedures for reference, we designed a procedure for the flipped college English classroom.

The first step: The teachers explain the difficult points and assign the tasks for the students. The difficult points are the problems that the students encountered when they are watching the teaching videos. That means that different classes may have different problems, so the pre-class communication is very important for this part. Then, the teacher would assign certain tasks for the students to complete, for example, practicing the dialogues or discussing certain topics.

The second step: The students complete the tasks in groups. Group collaboration is an effective form of classroom activity. Many tasks can be done by this way such as dictation. The students read the words in turn thus got more chances to learn the new words. Therefore, the students' learning effect may be improved. Another advantage of group collaboration is that the students can help each other and to get progress together.

The third step: The teachers communicate and guide the students. In this process, the teachers should try to give different kinds of guidance or advices according to the different learning characteristics of the students. Also, the teachers should encourage every student to use English to communicate with the teachers and other students.

The fourth step: The students and teachers summarize the learning procedure together. Group report is a good way in this part. Every group can show their learning result by different forms such as lectures, contests, performances, and so on. The students cannot only review what they have learned, improve their speaking ability, but also can use their imagination and creativity thus get a sense of achievement after this part.

\section{After-Class Activities}

Through pre-class and class activities, the students can get a good grasp of the basic content of the textbook. However, English is a language. We can hardly improve our language skill through only one or two classes every week. In a sense, we can say that the after-class activities are more important than the class activities.

For after-class activities, the teachers should assign certain tasks according to the characteristics of the students. The tasks can be a topic for the students to write, a film or short videos for them to watch to express their thoughts, a play script for them to play, and so on. The teachers should find an appropriate time to check the effects of the students' learning. The feedback the teachers give to the students would promote the students' learning in turn.

\section{College English Teaching Evaluation System}

Traditional college English teaching evaluation systems adopt the summative assessment. We think that the flipped classroom should adopt the formative assessment plus the summative assessment.

The formative assessment check the students' listening, speaking, reading, and writing ability by way of the teachers' observation, the group members' feedback, and so on. The summative assessments mainly check 
the students' learning condition of the textbook after a term's study. The major form is writing.

The teachers are already very familiar with the summative assessment because we have used it for years. More attention should be paid to the use of the formative assessment. This form of assessment is based on the teachers' observation, so it requires the teachers to make their own standards to reflect the students' real levels.

\section{The Challenges}

The flipped classroom is a newly emerged teaching mode, so people may need time to accept it. In addition, it is developed by the American teachers, so we should make certain changes to suit the current teaching conditions in China.

\section{The Challenges for the Teachers}

In the flipped classroom, the teachers' roles are changed. They are the makers and suppliers of the teaching resources. The teachers should know how to choose the suitable learning materials for the students and to use the related technology to make them into teaching videos. They are the guide of the students; they should know how to design different learning activities for the students. They are also the problem solvers. In the class, the teachers should answer any questions the students encountered. So it is necessary for the teachers to improve their own qualities.

The new roles give the teachers new tasks to complete. The teachers especially the old teachers may need a long time to adapt to the new teaching mode.

\section{The Challenges for the Students}

The students are in a sense changed from a knowledge receiver into a self-instructor. The teachers give the students the same learning materials but every student should choose their own learning points and ignore the parts they are already familiar with. The result of this part is that every student find out their own problems before the class and the teachers should try to solve different kinds of questions for all the students.

The new roles of the students give them a much higher demand. If the students do not preview the materials before the class, the flipped classroom would have no effect at all.

\section{The Challenges for the Teaching Environment}

First of all, the flipped college English classroom requires every classroom to be equipped with advanced equipment such as computers and multimedia. Now in China, most of the universities can have enough multimedia classrooms for English classes. However, the maintenance of the equipment is sometimes not so perfect. So it is necessary to keep the teaching equipment in a good condition in order not to affect the teaching effects. Secondly, besides the teaching videos the teachers made by themselves, the teachers may find many learning resources useful online. However, there are many resources which are outdated or even with wrong information, so the teachers should know how to choose the suitable resources from so many resources.

The flipped classroom presents many challenges for the college English teaching in China. But if we realized the problems and try to deal with them, the challenges can be turned into chances eventually.

\section{Conclusion}

According to WANG Xiao-dong, college English teaching should be different from that of the secondary schools. In college, the students should know how to study by themselves. In the college English classes, the teachers should help to solve the students' problems they are encountered after class and guide the students to 
study by themselves scientifically and effectively. The flipped classroom is a means that can help to realize such teaching objectives. It can help to promote the students to study and think independently; it may contribute to build a more harmonious relationship between the teachers and the students and it is also helpful to integrate the teaching resources reasonably. However, the reality is that our traditional teaching concepts are so strong that it is difficult to change them in a short period. In addition, the flipped classrooms make a higher demand for the teachers which is also a tough problem because the levels of the teachers are uneven. Therefore, it is in a sense that the flipped classroom is both a chance and a challenge for the Chinese college English teaching. Every college English teacher should try to design a teaching procedure for their own classes and make better changes while implementing the procedures.

\section{References}

Ash, K. (2012). Educators evaluate "flipped classrooms". Education Week, 32(2), 6-8.

Du, H. (2012). College English teaching in China: Responses to the new teaching goal. TESOL in Context Special Edition, S3.

Enfield, J. (2013). Looking at the impact of the flipped classroom model of instruction on undergraduate multimedia students at CSUN. TechTrends, 57(6), 14-27.

Fulton, K. P. (2012). 10 reasons to flip: A southern Minnesota school district flipped its math classrooms and raised achievement and student engagement. Phi Delta Kappan, 94(2), 20.

Graham, R. (2012). Commentary: The Khan academy and the day-night flipped classroom. Biochemistry and Molecular Biology Education, 5, 337-338.

HUANG, Y., LIU, J. Y., YIN, P. P., \& CHEN, L. (2014). Several reflections on the design of the "flipped classroom" teaching mode. Modern Educational Technology, 12, 100-106.

Hughes, H. (2012). Introduction to flipping the college classroom. In T. Amiel and B. Wilson (Eds.), Proceedings of EdMedia: World Conference on Educational Media and Technology 2012 (pp. 2434-2438). Association for the Advancement of Computing in Education (AACE).

Lage, M. J., Platt, G. J., \& Treglia, M. (2000). Inverting the classroom: A gateway to creating an inclusive learning environment. The Journal of Economic Education, 31(1), 30-43.

MacIsaac, D. (2011). "The Flipped Classroom" and Khan Academy video-lecture-based educational reform discussed by The Economist magazine, MSNBC, Salman Khan, and Frank Noschese. The Physics Teacher, 49(8), 526-526.

Sankey, M. D., \& Hunt, L. (2013). Using technology to enable flipped classrooms whilst sustaining sound pedagogy. Paper presented at Proceedings of the 30th Australasian Society for Computers in Learning in Tertiary Education Conference, ASCILITE, Sydney, Australia.

Strayer, J. F. (2012). How learning in an inverted classroom influences cooperation, innovation and task orientation. Learning Environments Research, 15(2), 171-193.

Tucker, B. (2012). The flipped classroom. Education Next, 12(1), 82-83.

WANG, X. D., \& ZHANG, C. J. Z. (2013). The applied research of "the flipped classroom" in the college teaching-taking the professional English courses for the educational technology as an example. Modern Education Technology, 23(8), 11-16.

WU, Q. D. (2004). On the direction of CET 4 \& CET 6 reform. Retrieved August 8, 2010 from http://www.edu.cn/20040219/3099260.shtml.

ZHANG, Y. G., \& ZHANG, Y. J. (2012). Perspective to the flipped classroom. Primary and Secondary Information Technology Education, 3, 8-10.

ZHU, H. J., \& ZHU, B. (2012). A rustic opinion on the flipped classroom and its effective implementation strategy. Research on the Electrified Education, 8, 79-83. 